\title{
A Era Vargas: desenvolvimentismo, economia e sociedade
}

\author{
Hermógenes Saviani Filho **
}

A menos de dois anos para completar sessenta anos do suicídio do presidente Getúlio Vargas, em 24/08/1954, a Editora Unesp edita uma coletânea de treze artigos, organizada pelos professores e pesquisadores Pedro Paulo Zahluth Bastos e Pedro Cezar Dutra Fonseca. O livro A Era Vargas: desenvolvimentismo, economia e sociedade apresenta um vasto panorama da trajetória política do homem que foi escolhido como o "maior brasileiro de todos os tempos" numa pesquisa organizada, em 2007, pelo jornal Folha de S.Paulo ${ }^{1}$. O matutino paulista convidou 200 personalidades brasileiras entre intelectuais, políticos, empresários, publicitários, jornalistas, esportistas e militares para escolherem e justificarem qual seria, o "Maior brasileiro(a) de Todos os Tempos". Na enquete, 70 nomes foram indicados, com Vargas recebendo 16 votos e vencendo, por apenas um voto, outro presidente, Juscelino Kubitschek. A presente obra ajuda a explicar porque, mais de meio século após sua morte, Getúlio continua presente no imaginário dos brasileiros.

Os organizadores procuraram dar uma coerência ao encadeamento dos artigos a partir de uma ordem cronológica. É bom frisar que existe uma coesão de pensamento entre os autores - não pense em encontrar algum texto de tendência neoclássica ou de antigos críticos do varguismo. Como o subtítulo informa, a preocupação é a opção desenvolvimentista adotada nos quase dois decênios em que Vargas permaneceu no poder (1930/45 e 1951/54) e o seu legado. Dessa forma, o livro aparece num momento de renascimento da economia brasileira e da opção política pela retomada da ideia de desenvolvimento econômico.

A coletânea pode ajudar a mudar algumas concepções de uma parte da sociedade brasileira, pois, na pesquisa em questão, nenhum empresário votou em Vargas, enquanto Juscelino recebeu, em quinze votos, três desse grupo - como se fosse possível dissociar a influência daquele sobre este. Outro segmento que pode modificar determinados pontos de vista é a política, pois, em 2007, apenas um um político votou no gaúcho, enquanto quatro votaram em JK.

Como citado na apresentação do livro, Getulio Vargas consolidou-se na memória coletiva brasileira pela sua Carta Testamento e pela imagem negativa (ditador, demagogo, caudilho) consagrada pelos seus opositores. O editorial do jornal O Estado de S.Paulo, ao saudar o golpe de 1964, decretou o fim do legado varguista. O ex-presidente Fernando Henrique Cardoso, em discurso de despedida do Senado, em dezembro de 1994, proferiu as

* Resenha de: Bastos, Pedro Paulo Z.; FOnSECA, Pedro Cezar D. (Org.). A Era Vargas: desenvolvimentismo, economia e sociedade. SãoPaulo: Editora Unesp, 2012.

** Professor Adjunto do Departamento de Economia e Relações Internacionais da Universidade Federal do Rio Grande do Sul (UFRS. DERI), Porto Alegre, RS, Brasil. E-mail: hermogeness@ yahoo.com.

(1) Publicada no Caderno Poder de 1 abr. 2007. 
seguintes palavras: "O caminho para o futuro desejado ainda passa, a meu ver, por um acerto de contas com o passado. Eu acredito firmemente que o autoritarismo é uma página virada na história do Brasil. Resta, contudo, um pedaço do nosso passado político que ainda atravanca o presente e retarda o avanço da sociedade. Refiro-me ao legado da Era Vargas“. Como os próprios autores definiram, a obra é uma tentativa de decifrar o que já foi denominado o "enigma Vargas".

Vargas é o construtor do moderno Estado brasileiro. Além de ser o líder da transformação de uma economia agrárioexportadora voltada para fora em outra industrializada e voltada para dentro, ele criou instituições que contribuíram para o desenvolvimento econômico e social do país. A Consolidação das Leis do Trabalho ainda é o arcabouço geral de regulação das relações de trabalho; sem mencionar o salário mínimo; a ampliação do crédito agrícola via programas do governo federal e de carteiras do Banco do Brasil; a criação do BNDES, que ainda financia boa parte dos investimentos na indústria e na infraestrutura; a criação das companhias Vale do Rio Doce e Siderúrgica Nacional (ambas em 1942) e da Petrobrás (em 1954).

O primeiro artigo do livro, Gênese e Precursores do Desenvolvimentismo no Brasil, de Pedro Fonseca, dá o norte e alinhava toda a obra: o desenvolvimentismo brasileiro. Esse fenômeno, historicamente novo, se forma através de quatro correntes: industrialização, intervencionismo pró-crescimento, nacionalismo e positivismo. A partir desses pontos - e de outros secundários -, os demais textos procuram mostrar como tais questões influenciaram a política econômica varguista nos quase 20 anos de governo no Brasil. O desenvolvimentismo de Vargas foi colocado em prática durante o governo do Rio Grande do Sul, em 1928. Esse foi o laboratório para romper com a "vocação natural" do Brasil para a especialização primário-exportadora e com os dogmas liberais dos mercados autorregulados. Será, por outro lado, o positivismo que dará ao desenvolvimentismo a noção de linha evolutiva e de práxis - intervenção do Estado na economia e ajuda à sociedade a rumar para o progresso, sociedade que desconhecia os direitos naturais do liberalismo, que associava os direitos, como o de propriedade, a determinado grau da evolução social e os subordinava ao bem comum, adepta do equilíbrio no balanço de pagamentos - e que levaria à intencionalidade do desenvolvimento econômico discutida em Instituições e Política Econômica: Crise e Crescimento do Brasil na Década de 1930.

Nesse artigo, Fonseca mostra que, diferentemente do que Celso Furtado, Carlos Lessa e Warren Dean pensavam, havia intencionalidade e consciência do governo quanto à consecução da política industrializante no Brasil na década de 1930. A sua explicação será apoiada no pensamento institucionalista, associada a estruturas, organizações ou conjunto de leis. Dessa forma, a consciência da opção industrializante pode ser demonstrada pelas instituições criadas e alteradas no período.

Luiz Carlos Bresser-Pereira, no artigo Getúlio Vargas: o Estadista, a Nação e a Democracia, define Vargas como um estadista, pois teve a capacidade de se antecipar aos fatos e liderar as forças políticas em direção a novos rumos. A análise que faz sobre o Estado Novo é polêmica: "Vargas foi um estadista porque teve a visão da oportunidade que a Grande Depressão dos anos 1930 abria para o Brasil iniciar sua industrialização e 
completar sua revolução nacional e capitalista". Este ponto de vista surge e "embora ele próprio fosse autoritário, não era elitista. Foi a primeira vez na história política do Brasil que um grande líder político foi buscar as bases de sua legitimidade no povo". Apesar de pertencer a elite agrária, "se definiu como um político antes de esquerda do que de direita, na medida em que fundou o primeiro partido de massas do país, o Partido Trabalhista Brasileiro". Apesar de todo rótulo que lhe foi posto ao longo da história, "Vargas é com frequência chamado de 'ditador' devido ao Estado Novo (1937-1945), o que, tecnicamente, é correto. É preciso considerar, no entanto, que o Estado Novo foi uma forma de completar a revolução econômica, política e social, iniciada em 1930". Entretanto, mesmo esse rótulo deve ser relativizado, pois, se "Vargas errou ao decidir embarcar no Estado Novo, não teria sido o estadista que foi se houvesse então realizado eleições e transferido o governo para um novo presidente eleito".

Ângela de Castro Gomes, no ensaio Autoritarismo e Corporativismo no Brasil, investiga a corrente de pensamento autoritária a que se alinhou Vargas depois de $1930 \mathrm{e}$ destaca a contribuição dos intelectuais Oliveira Viana, Francisco Campos e Azevedo Amaral à formação do projeto do Estado Novo, ressaltando a identificação entre Estado e nação aliada à concentração da autoridade do Estado na figura do presidente e a ligação direta entre governante e povo sem a necessidade de intermediários, ou seja, sem a necessidade de partidos e assembleias que traduzissem interesses particulares e desagregadores. Estava, dessa forma, instaurada uma nova modalidade de Estado forte, centralizado e antiliberal, sem perder a conotação democrática, isto é, um Estado justo e protetivo. O Brasil começava a estruturar um Estado nacional moderno que ampliava suas funções de intervencionismo econômico e social ao mesmo tempo em que montava a estrutura de um estado burocrático segundo os moldes weberianos. Surgia o modelo brasileiro de Estado autoritário e democrático pós-1930. Estávamos diante de uma "modernização" das tradições do poder privado e do personalismo, assim como da afirmação do poder público via burocracia e de um modelo alternativo de representação política: o corporativismo. Essa nova característica que surge na política brasileira ajuda a explicar porque figuras carismáticas estariam sempre no horizonte do imaginário político brasileiro. O modelo referencial básico continua sendo Vargas.

O capitalismo brasileiro nasceu com a introdução da mão de obra assalariada na economia cafeeira do Oeste Paulista, no decênio de 1880. Para prosseguir com o desenvolvimento desse capitalismo, era necessário integrar o mercado nacional, não mais permitindo a supremacia dos interesses regionais sobre os nacionais, o que vinha ocorrendo durante a República Velha (1889-1930). A questão que se colocava quando Vargas assumiu o poder no final de 1930 era como integrar o mercado nacional, necessário para que houvesse maior soberania nacional, além do interesse predominante do desenvolvimento da indústria prioritariamente aos demais setores. E é essa realização de Vargas que Wilson Cano demonstra em Crise de 1929, soberania na política econômica, ao rejeitar a tese de que a recuperação da década de 1930 resultou de políticas inconscientes ou foi atrapalhada por políticas econômicas ortodoxas.

Nos anos 30, para que a indústria brasileira desse um salto qualitativo, foi necessário não apenas que o Estado tivesse uma participação ativa devido à presença 
inexpressiva da indústria de bens de capital mas também a mobilização de capitais nacionais e de recursos externos que, naquele momento, eram escassos em decorrência da crise internacional que também acabava por influenciar o fraco desempenho das exportações.

Esses pontos são discutidos por Francisco Luiz Corsi em $O$ Projeto de Desenvolvimento de Vargas, a Missão Oswaldo Aranha e os Rumos da Economia Brasileira. O autor vai costurando o delicado momento, principalmente pela via das relações internacionais e das discussões do governo brasileiro com o estadunidense. Com o mundo caminhando mais e mais para um conflito bélico generalizado, os países latinoamericanos passaram a ser disputados por EUA e Alemanha. O governo Vargas aproveitou o acirramento das disputas imperialistas para adotar uma política externa mais independente, aproximando-se comercial e militarmente da Alemanha. Além disso, em 1937, o governo decretou a moratória da dívida externa e reintroduziu o monopólio do câmbio, medidas necessárias para enfrentar a crise cambial. O início do Estado Novo marca o começo do projeto de desenvolvimento nacional calcado na indústria. O projeto da Companhia Siderúrgica Nacional surge nesse momento. Além disso, o governo iria perseguir a garantia da unidade nacional e acabar com a dicotomia entre os "dois Brasis" um político e outro econômico, que não coincidiam.

Os discursos de Vargas procuravam vincular o desenvolvimento econômico à superação da miséria e à consolidação da unidade nacional. A unidade nacional só viria através do Estado, via uma política integradora. Como destaca Bastos no artigo $A$ Construção do Nacionalismo Econômico de Vargas, o desenvolvimento industrial não era apenas um fato econômico, pois, desde cedo, Vargas considerava que o radicalismo político das massas seria um resultado inevitável de um Estado economicamente omisso, que mantivesse milhares de trabalhadores famintos e fora do mercado de trabalho. Seria necessário fazer a reforma do capitalismo e da rede urbana de proteção social antes que o povo fizesse a revolução. Com reduzida entrada de capital estrangeiro, a saída era financiar o desenvolvimento via capital nacional. A solução foi estimular o crédito através do Banco do Brasil. Apesar de o governo ter flertado com o desenvolvimento nacional autônomo, ele nunca abandonou a ideia de o capital estrangeiro ser fundamental no processo de desenvolvimento. A política econômica varguista não era nem xenófoba quanto ao capital estrangeiro, nem "entreguista", era, na verdade, flexível, oportunista e politicamente realista.

A paixão e os debates acalorados que cercam a mítica figura de Vargas devem-se ao fato de que, como bem destaca Jorge Ferreira no artigo Os conceitos e seus lugares: Trabalhismo, Nacional-Estatismo e Populismo, existiram vários Getúlios: o político da Primeira República, o líder da Revolução de 1930 e chefe do governo provisório, o presidente constitucional de 1934, o ditador do Estado Novo de 1937 e o presidente eleito democraticamente em 1951.

Vargas governou como ditador e democrata; foi reformador social e enquadrou sindicatos; censurou a Imprensa e patrocionou o cinema, o teatro, as artes plásticas e a literatura; perseguiu comunistas e fundou a Petrobrás. Só é possível analisar e compreender 
o mito pelo todo, pois foi o seu grupo político que, ao assumir o poder em 1930, criou o moderno Estado brasileiro, com uma burocrácia técnica, impessoal, baseada no mérito. $\mathrm{O}$ Estado passa a ser interventor, regulador e planejador. O nacional-estatismo teve como forma particular no Brasil o trabalhismo. Se, no segundo governo, o projeto trabalhista foi mais consistente, durante o Estado Novo, foi renomeado de populismo, detratando-o com a pecha de demagogia, corrupção e irresponsabilidade administrativa. Essa tese passa a ganhar corpo e forma após o Golpe Militar de1964. Foi, contudo, o livro O populismo na política brasileira, de Francisco Weffort, que deu o estofo acadêmico ao conceito. Em meados dos anos 1980, surgem as primerias versões alternativas com análises que apontavam para interações entre o projeto getulista e as demandas dos trabalhadores antes de 1930. A consciência de classe foi interpretada como uma complexa interação dos trabalhadores com o Estado e os empresários. Os sindicalistas não seriam pelegos à espera de líderes populistas, mas buscavam formas de manterem e ampliarem os seus direitos trabalhistas e, principalmente, próximos dos operários, que, diferentemente das interpretações tradicionais, tinham consciência de classe.

Em A "Política do Exército" no Primeiro Governo Vargas: 1930-1945, Lígia Osório e Silva discute o envolvimento da cúpula do Exército com a ideologia do desenvolvimento econômico nacional. A autora discute as razões que levaram os militares a se engajarem com a necessidade de industrialização e a tentativa de explicar as razões que fizeram com que esse envolvimento resvalasse para o militarismo político. Os miltares forneciam mão de obra especializada de caráter técnico-administrativo. O movimento tenentista de 1922 e 1924 deixava claro a insatisfação das Forças Armadas com a coligação que sustentava a República Velha. Para a instituição, sua missão era tirar o Brasil do atraso no qual o particularismo das elites agrárias regionalistas o mantinha. $\mathrm{O}$ movimento, no entanto, não era hegemônico, e essa unidade foi obtida pelo caráter amplo da Revolução de 1930 e a figura conciliadora de Vargas. Se, ao final do seu primeiro governo, toda a corporação militar era adepta do desenvolvimentismo, havia, entretanto, aqueles que se dividiam entre os que identificavam e separavam os ideais de desenvolvimento econômico e as aspirações de desenvolvimento social. Essa unidade só foi atingida em 1964, via expurgo dos dissidentes.

No artigo Ascensão e Crise do Projeto Nacional-Desenvovimentista de Getúlio Vargas, Bastos mostra que a estratégia de Vargas de voltar ao poder começa com discursos oposicionistas ao governo Dutra, que se intensificam durante a campanha. Esse norte político o levaria a repudiar a política anti-inflacionária do governo ao rejeitar a ortodoxia econômica e ao articular coerentemente a gestão da política macroeconômica ao projeto de desenvolvimento econômico e social. O "direito ao trabalho" deveria se sobrepor à ortodoxia monetária, que não poderia ter como consequência o desemprego em massa. Além disso, para superar a "pauperização" e obter a coesão social, o governo teria que financiar a industrialização. Ao retornar ao poder, o programa de governo se orientaria para um novo perfil industrial ancorado na produção de insumos básicos de bens de capital, superando as restrições de desenvolvimento econômico. O Estado, portanto, realizaria ou induziria os investimentos essenciais para superar os pontos de estrangulamento. As políticas macroeconômicas se implementariam com a expansão do crédito para fomentar a 
produção e combater a inflação, e a política cambial seletiva fomentaria a substituição de importações, enquanto a política fiscal concentrar-se-ia em evitar déficits e aumentar os recursos para investimentos públicos nos ramos básicos. No entanto, o plano fracassou por três razões: a crise sociopolítica interna, a crise da política externa e a crise cambial.

O projeto nacional varguista não foi capaz de superar as restrições políticas e econômicas, realizar a industrialização pesada e converter a burguesia nacional, elites políticas e militares ao ideário trabalhista de justiça social. No entanto, o suicídio de Getúio Vargas adiou o golpe conservador e permitiu a instituição do Plano de Metas de Kubitschek e a consolidação do ideário desenvolvimentista e trabalhista. Essa conclusão de Bastos, que encerra a coletânea, é o elo entre todos os artigos e resgata a importância do período e de suas instituições para a nossa história recente.

A "Era Vargas" constitui-se num conjunto de políticas públicas para o país e no ambicioso objetivo de alcançar certa autonomia política e econômica através de um desenvolvimento nacional independente baseado num Estado forte, centralizado e planejador. Podemos concluir que Vargas foi o homem que sintetizou o processo da complexa transição da República Velha para o moderno Estado brasileiro.

Após quase 13 anos que nos separam das palavras proferidas pelo ex-presidente Fernando Henrique Cardoso quando da eleição realizada pelo jornal paulista, Getúlio Vargas permanece presente entre os brasileiros, enquanto FHC, mesmo tendo recémencerrado seu mandato como presidente, não obteve nenhum voto. A própria imprensa saiu derrotada, pois Vargas, quando eleito em 1950, não contou com apoio de nenhum veículo publicitário. Na verdade, foi hostilizado pela imprensa e recebido pelo povo com imenso carinho. Mesmo após sua eleição, a imprensa não deixou de fazer uma oposição acirrada, estimulando a sua derrubada aliada à oposição golpista, representada pela figura da UDN, que defendia abertamente um golpe preventivo. Qualquer semelhança com o atual momento não é mera coincidência!

O término da carta Getúlio mostra o sentimento de uma época que, diante dos últimos acontecimentos na nossa sociedade, permanece atual: "Quando vos humilharem, sentireis minha alma sofrendo ao vosso lado. Quando a fome bater à vossa porta, sentireis em vosso peito a energia para a luta por vós e vossos filhos. Quando vos vilipendiarem, sentireis no pensamento a força para a reação. [...] Lutei contra a espoliação do Brasil. Lutei contra a espoliação do povo. Tenho lutado de peito aberto. $\mathrm{O}$ ódio, as infâmias, a calúnia não abateram meu ânimo. Eu vos dei a minha vida. Agora vos ofereço a minha morte. Nada receio. Serenamente dou o primeiro passo no caminho da eternidade e saio da vida para entrar na História". 